\title{
The Time of Preparation for the Pasch in the Light of Medieval Allegory
}

\author{
WALDEMAR PAŁĘCKI MSF
}

The John Paul II Catholic University of Lublin

waldemar.palecki@kul.pl, ORCID: 0000-0002-2154-9356

\begin{abstract}
In the medieval liturgy, especially in the celebration of the Mass, allegorical interpretation of the texts and gestures played a very meaningful role. Among the most prominent representatives of the allegorical interpretation of the liturgy were: Isidore of Seville, Alcuin, Amalarius of Metz, Rabanus Maurus, Walafrid Strabo, Rupert of Deutz, John Beleth, Pope Innocent III, and William Durand. These ideas were laid out in treatises with the titles Expositiones Missae, Rationale Divinorum Officiorum, or Liber de Divinis Officiis. This study presents the allegorical interpretation of the paschal preparation period, from Septuagesima Sunday to Holy Saturday, and its associated liturgical rites.
\end{abstract}

Keywords: Allegory, Medieval Liturgy, Septuagesima Sunday, Sexagesima Sunday, Quinquagesima Sunday, Lent

At the center of Christian celebration is found the Paschal Mystery, which is the recalling of the passion, death, and resurrection of Christ. With the development of the liturgical year, the celebration of this mystery came to be preceded by a period of preparation. Over the centuries, the length of the preparation time before the Pasch has changed. In the beginning, it consisted of the two days before Easter: Friday and Saturday, as indicated in the Didascalia Apostolorum in the $3^{\text {rd }}$ century. ${ }^{1}$ In Syria there was also a tradition of keeping a fast from Monday to Thursday of Holy Week. Only in the $4^{\text {th }}$ century was this period extended to forty days; this practice was influenced by the preparation of catechumens as well as by customs of public penance. ${ }^{2}$ Since the Council of Nicea in 325 this time has been referred to as the Quadragesima Paschae. $^{3}$

During the $6^{\text {th }}$ to the $8^{\text {th }}$ centuries the preparation time for the Pasch was next extended to the three Sundays preceding it, known as Septuagesima, Sexagesima, and Quinquagesima. This was first introduced in the East. The reason for this was the fact that no fast was observed there on Saturdays or Sundays, and the faithful

\footnotetext{
Cf. The Didascalia Apostolorum in English, 99.

Cf. Auf der Maur, Feiern im Rhythmus der Zeit, 144-145.

Cf. Baron - Pietras, Dokumenty soborów powszechnych, I, 30.
} 
wanted to keep a fast of exactly forty days. ${ }^{4}$ In the West, on the other hand, the earliest known pre-Lenten fast period was observed by a religious community in Gaul. Saint Caesarius of Arles (d. 542) instructed his monks to keep a fast for the two weeks preceding the "Paschal Forty Days." The existence of this practice in Gaul is confirmed by the Councils of Agde and Orleans in the first half of the $6^{\text {th }}$ century. ${ }^{6}$ The Gelasian Sacramentary witnesses to the practice of the three pre-Lent Sundays in the $7^{\text {th }}$ century in Rome. ${ }^{7}$ After the Carolingian Renaissance of the $8^{\text {th }}$ century this custom became universal in the western Church. ${ }^{8}$

The formation of the paschal preparation period coincides with the era when the western Church was developing allegorical interpretation of the liturgy, the roots of which date back to the Church in the East in the $4^{\text {th }}$ and $5^{\text {th }}$ centuries. ${ }^{9}$ This form of interpreting the liturgy became popular in the West beginning in the $8^{\text {th }}$ century and it denoted a manner of explaining rites and liturgical texts through the help of images or stories. ${ }^{10}$ The allegory characterizes the composition method of "hiding" an important truth beneath a literal text, or the hermeneutic method of "discovering" another meaning in a literal text. ${ }^{11}$ The precursor of the allegoric conceptualization of the liturgy was St. Isidore (d. 636), Archbishop of Seville, and among its chief proponents was Alcuin of York (d. 804), the best-known theologian of the Carolingian Renaissance. ${ }^{12}$ Following on this path of theological interpretation of the liturgy were also Amalarius of Metz (d. c. 850), Rabanus Maurus (d. 856), Walafrid Strabo (d. 849), Rupert of Deutz (d. 1129), John Beleth (d. c. 1183), Pope Innocent III (1198-1216), and Wilhelm Durand (d. 1296). It also found echoes in the works of early Scholastic authors Hugo of St. Victor (d. 1141) and Honorius of Autun (d. c. 1150). These views were included in the treatises Expositiones Missae, Rationale divinorum officiorum or the Liber de divinis officiis. Although allegoric interpretation was criticized, it nonetheless became the basic form for explaining the liturgy in the Middle Ages. ${ }^{13}$ Allegoric interpretation of the liturgy concerned principally the Holy Mass, which was seen as the image of the whole of salvation history, and first and foremost, of the passion of Christ. ${ }^{14}$ Some authors have left works dedicated mainly to this topic,

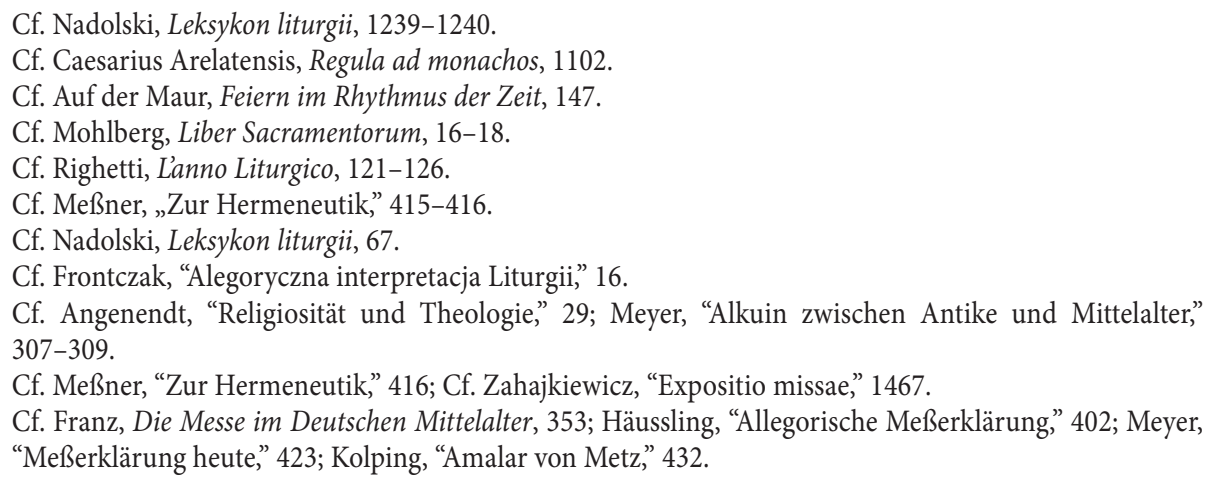


examples of which include the writings of Walafrid Strabo ${ }^{15}$ and Pope Innocent III. ${ }^{16}$ Other areas of the liturgy were also interpreted according to this method: the other sacraments, sacramentaries, the Officium Divinum, and the liturgical year. ${ }^{17}$ The purpose of this study will be to show how the time of paschal preparation from Septuagesima Sunday to Easter, and the accompanying liturgical rites, were interpreted in the light of the allegorical construct. It will be of the essence to focus on the content submitted by these theologians and on whether over the centuries they were dependent upon each other in interpreting the paschal preparation period.

Although much has been written on the topic of allegoric interpretation of the Mass, few authors have undertaken issues regarding the presentation of other areas of the liturgy in the writings of medieval theologians. It was therefore necessary to reach back to the original texts and examine the writings of the allegorists regarding their interpretations of the paschal preparation period.

\section{Calculation and Interpretation of the Paschal Preparation Time- Pre-Lenten Period}

In medieval interpretation, authors discussing the paschal preparation period put priority on the significance of numbers. The Venerable Bede explained the manner of calculating the individual periods. He stressed that the paschal preparation period ended on the Saturday of the Easter Octave, creating a total of ten weeks and producing seventy days. Sexagesima-according to his calculations-encompassed the period up to Wednesday of the Easter Octave (feria quarta), that is to say, eight weeks and four days. Quinquagesima covered the time up to the Sunday of the Resurrection of the Lord, in other words eight weeks and one day. Quadragesima was calculated from the First Sunday of Lent to Holy Thursday, forming a total of five weeks and five days. The author underscored that from Septuagesima to Quadragesima there are eighteen days, excluding Sundays. This number can be considered as a ratio of one to two (six to twelve). He also derived this ratio from the manner of calculating the time of Lent, stressing that in accordance with the already-fixed ending times of the particular periods of fast, six days are left over: in other words, the time between Holy Thursday and the Day of the Resurrection, between the Day of the Resurrection and Wednesday of the Easter Octave, and between the Wednesday and Saturday of the Octave of Easter. These numbers, in his thought, can also be seen as a ratio of one to two (two to four). This manner of calculating the time of Lent allowed the Venerable Bede to

\footnotetext{
15 Comp. Walafridus Strabus, De ecclesiasticarum rerum exordiis et incrementis (PL 114, 919-966).

16 Comp. Innocentius III, De sacro altaris mysterio. Libri sex (PL 217, 773-916).

17 Cf. Frontczak, "Alegoryczna interpretacja Liturgii Godzin," 18.
} 
relate this content to a theology of dying - the dual death of man, of the soul and of the body, and the single-corporal-death of Jesus. ${ }^{18}$ Other medieval theologians also made reference to this theology. Alcuin explained the method of calculating the time of Lent in the same manner in 798 in his letter to Charlemagne, ${ }^{19}$ and also in his De Divinis Officiis Liber. ${ }^{20}$ Wilhelm Durand also refers to this explanation. ${ }^{21}$

In his writings, in addition to mathematical interpretation, Rabanus Maurus said that this time can be understood as a synecdoche, showing a dependence between the numbers wherein the smaller number is within the larger one. He also pointed out the differences in the length of this time. He reported that the faithful in the East fasted nine weeks, the Greeks eight, and the Latins seven..$^{22}$ Amalarius of Metz made the same observation. Desiring to account for the meaning of this time, the author on the one hand interprets it as the time of Israel's bondage in Babylon, and on the other hand, as a return to God in His rest. ${ }^{23}$ The Babylonian captivity was a special experience of the Chosen People when the entire country was laid to waste and the nation itself forced to serve the Babylonian kings for seventy years (cf. Jer 25:10-12). Rupert of Deutz, ${ }^{24}$ Hugo of St. Victor, ${ }^{25}$ Honorius of Autun, ${ }^{26}$ John Beleth, ${ }^{27}$ and Wilhelm Durand $^{28}$ also all refer to this same biblical event. This reference to the Babylonian captivity was known earlier in the history of the Church, as evidenced by surviving homilies of the Ambrosian tradition from the $4^{\text {th }}$ century. ${ }^{29}$ The occurrence of seventy years of Babylonian slavery was also interpreted in the eschatological sense. One example is the Venerable Bede, who noted that the number seventy is meant to recall the time which separates a person from the Heavenly Jerusalem..$^{30}$ This idea was highlighted by Alcuin, as well. ${ }^{31}$ The relationship between the seventy years of Babylonian captivity and the seventy days of fasting was also allegorically interpreted in the writings of medieval theologians. Amalarius of Metz taught that by the grace of Christ the sins of humanity have been forgiven and, since Christians freely bear humiliations rather than doing so unwillingly - as was the case in the times of the Babylonian captivity - this period of penance was reduced to seventy days. ${ }^{32}$

\footnotetext{
Cf. Beda Venerabilis, De Officiis libellus (PL 94, 534).

Cf. Alcuinus, Epistola LXXX (PL 100, 260-261).

Cf. Alcuinus, De divinis officiis (PL 101, 1183-1184).

Cf. Davril - Thibodeau, Gvillelmi Dvranti Rationale, 228-229.

Cf. Rabanus Maurus, De clericorum Institutione (PL 107, 364).

Cf. Amalarius, De ecclesiasticis officiis (PL 105, 993).

Cf. Rupertus, Liber de divinis officiis (PL 170, 87).

Cf. Hugo de S. Victore, De caeremoniis, sacramentis (PL 177, 443).

Cf. Honorius Augustodunensis, Gemma animae (PL 172, 652-653).

Cf. Joannes Belethus, Rationale divinorum officiorum (PL 202, 82).

Cf. Davril - Thibodeau, Gvillelmi Dvranti Rationale, 223.

Cf. Monumenta vetera ad Arianorum historiam pertinentia, IV (PL 13, 644).

Cf. Beda Venerabilis, De Officiis libellus (PL 94, 532).

Cf. Alcuinus, De divinis officiis (PL 101, 1182).

Cf. Amalarius, De ecclesiasticis officiis (PL 105, 993).
} 
Rupert of Deutz interpreted the pre-Lenten period in a manner different from earlier theologians. He related the paschal preparation period to the seven epochs of the earth: 1. from Adam to Noah; 2. from Noah to Abraham or Moses; 3. from Moses to David; 4. from David to the displacement in Babylon; 5. From the displacement in Babylon to the coming of the Lord; 6. From the arrival of Christ to the end of the world; 7. denotes the Heavenly Jerusalem, into which will enter the elect. ${ }^{33}$

Amalarius of Metz, discussing the fasting period beginning on Septuagesimareferencing the prophet Jeremiah-explained that this is a period when the Church is in exile and for this reason it is dominated by oppression and sadness. It is characterized by the silencing of the voice of joy (cf. Jer 7:34), which is expressed in the liturgy by the omission during this period of the singing of the Gloria and the Alleluia. The psalm expresses this: "But how could we sing a song of the Lord in a foreign land?" (Ps 137:4). Amalarius of Metz calls these songs heavenly songs, because they can resound only in the Heavenly Jerusalem. ${ }^{34}$ Such singing can only sound in the mouths of those who have been reborn in water and the Spirit (cf. John 3:5), as Rupert of Deutz stressed. ${ }^{35}$ Alcuin, meanwhile, explains that these are heavenly hymns and so cannot be sung in a period dedicated to penance and fasting ${ }^{36}$ John Beleth also accented that this is a period when the Church prays, bends the knee, and fasts (Breviter ergo tum temporis Ecclesia orat, flectit genua, ac ieiunat). ${ }^{37}$

The Sexagesima period, in the teaching of Amalarius of Metz, begins on the Sunday following Septuagesima and continues to Wednesday of the Easter Octave. He explained that this is the first perfect number, as a sixth of it is one, a third of it is two, half of it is three, and one plus two plus three gives the sum of six. This number also confirms the perfection of God's work of creation. At the same time, Amalarius of Metz noted that this number multiplied in denarii-which contain ten units-as a day's wages, indicates payment in the Kingdom of Heaven (cf. Matt 20:1-14). ${ }^{38}$ Similarly, this manner of calculation was repeated in the writings of Hugo of St. Victor, ${ }^{39}$ John Beleth ${ }^{40}$ and Wilhelm Durand. ${ }^{41}$ According to Rupert of Deutz Sexagesima is an image of the epochs of the earth, in which a sower goes out to sow (cf. Luke 8:5), and in this way prepares the world for reconciliation with God. ${ }^{42}$ In the thinking of Honorius of Autun this period represents the Church being forsaken by her Spouse. ${ }^{43}$

\footnotetext{
33 Cf. Rupertus, Liber de divinis officiis (PL 170, 88).

34 Cf. Amalarius, De ecclesiasticis officiis (PL 105, 995-996).

35 Cf. Rupertus, Liber de divinis officiis (PL 170, 90-91).

36 Cf. Alcuinus, De divinis officiis (PL 101, 1182).

37 Cf. Joannes Belethus, Rationale divinorum officiorum (PL 202, 62).

38 Cf. Amalarius, De ecclesiasticis officiis (PL 105, 999).

39 Cf. Hugo de S. Victore, De caeremoniis (PL 177, 448).

40 Cf. Joannes Belethus, Rationale divinorum officiorum (PL 202, 84).

41 Cf. Davril - Thibodeau, Gvillelmi Dvranti Rationale, 228.

42 Cf. Rupertus, Liber de divinis officiis (PL 170, 93).

43 Cf. Honorius Augustodunensis, Gemma animae (PL 172, 653).
} 
Sexagesima, according to Hugo of St. Victor, evokes the fourth epoch, when David and Solomon reigned, and which foretells the future Kingdom of Christ. ${ }^{44}$ Wilhelm Durand referred to this representation, pointing out that this time period consisted of six decades. He noted that the number six denotes the works of mercy, and that ten denotes the decalogue, and just as God blessed the seventh day after six days, so by keeping the decalogue the faithful will come into eternal glory. ${ }^{45}$

The Sunday preceding the forty-day fast was called Quinquagesima. Amalarius of Metz alluded to this number, saying that it signifies all the good works of the five senses of the body. Multiplying this number by the ten words of the Law, which man fulfills in the Holy Spirit, gives the number fifty. This is a pledge of the celebration of the Pasch of the Lord. ${ }^{46}$ For Hugo of St. Victor, Quinquagesima was the period ending on Resurrection Sunday ${ }^{47}$ According to Rupert of Deutz this Sunday is an image of the third epoch of the earth. This period is called the "time of love" (cf. Ezra 16:8) and represents the time in which God strengthened the growing Church and liberated it, as He did with the Israelites from their slavery in Egypt, using Moses and Aaron. ${ }^{48}$

In allegorical interpretation, medieval authors interpreted the pre-Lenten period as a whole. An example of this is the writings of Alcuin, who stressed that on Septuagesima Sunday the people embrace sadness and affliction, on Sexagesima the Lord is called upon by the faithful to awaken, as if from sleep, while on Quinquagesima Day there is a more intense call, that He show forth His salvation. ${ }^{49}$ Amalarius of Metz compared this time to the three stages of the human person being set free: the weeping of prisoners who do not want to be under the control of their vices; the second stage, a desire to escape; and the third, betokening strife.$^{50}$ He portrayed the three stages of the release of the enslaved Israelites in this way-starting with Septuagesima Sunday - that is, their emergence from slavery in Babylonian to the fullness of freedom. The first stage took place under the leadership of Zerubbabel and the high priest Jeshua, when 50,000 people returned (cf. Ezra 3:1). The second return took place during under Ezra (cf. Ezra 8:31-33), and the third under the leadership of Nehemiah (cf. Neh 2:10-11). ${ }^{51}$ Wilhelm Durand refers here to Ezra as an aide (auditor), and to Nehemiah as a consoler (consolator) and likens these persons to the Holy Spirit and to Christ, respectively, thanks to whom the faithful return to their homeland

\footnotetext{
Cf. Hugo de S. Victore, De caeremoniis (PL 177, 444).

Cf. Davril - Thibodeau, Gvillelmi Dvranti Rationale, 239.

Cf. Amalarius, De ecclesiasticis officiis (PL 105, 999).

Cf. Hugo de S. Victore, De caeremoniis (PL 177, 444).

Cf. Rupertus, Liber de divinis officiis (PL 170, 94-95).

Cf. Alcuinus, De divinis officiis (PL 101, 1189).

Cf. Amalarius, De ecclesiasticis officiis (PL 105, 1000).

Cf. Bettenzoli, „Księga Ezdrasza i Księga Nehemiasza,” 598-602.
} 
and experience the twofold joy of worshiping God in spirit and in body. ${ }^{52}$ The seven weeks from Quinquagesima up to the Pasch is in turn for Honorius of Autun an image of the seven means of forgiveness of sins, which are: baptism, martyrdom, almsgiving, absolution, preaching, charity, and penance. ${ }^{53}$

When explaining the time of fast, medieval authors called attention to its genesis, making reference to the Liber Pontificalis. ${ }^{54}$ Amalarius of Metz recalled that the custom of keeping a fast from Quinquagesima was initiated by Pope Telesphorus (125-136?). ${ }^{55}$ Rupert of Deutz also referred to this, stating that the period was introduced as a countermeasure against a slackening in the practice of penance amongst the faithful..$^{56}$ According to Rabanus Maurus there was a correlation between the seven weeks of fasting and the seven weeks of Easter. It is necessary to fast and offer prayers because of sins committed, in order to merit the mercy of God, and, after Easter, to persevere in prayer of praise in order to merit the graces of the Holy Spirit. ${ }^{57}$ Extending this time to eight weeks and introducing Sexagesima Sunday, medieval theologians united themselves with the person of Pope Miltiades (311-314). For he had decreed that since fasting was not allowed on the first and fifth days of the week, because of celebrating the Resurrection and the Last Supper, then the time of fasting should be extended by another week. ${ }^{58}$ The medieval authors were relying on the information available at that time, whereas it is now known that the pre-Lenten period in Rome was not introduced until the seventh or eighth century.

Medieval theologians portrayed the pre-Lenten fast period chiefly on the basis of interpretation of numbers and on biblical texts. A characteristic feature was that they did not interpret them literally but figuratively, treating them as illustrations for their allegorical arguments.

\section{The "Forty Days before the Pasch" Period - Quadragesima Paschae}

Since the seventh century, the time of the "Forty Days before the Pasch" (Quadragesima Paschae) has begun on the Wednesday before the First Sunday of Lent, with

\footnotetext{
52 Cf. Davril - Thibodeau, Gvillelmi Dvranti Rationale, 228.

53 Cf. Honorius Augustodunensis, Gemma animae (PL 172, 657).

54 Cf. Ożóg - Pietras, Księga Pontyfików 1-96, IX, $22^{*}$.

55 Cf. Amalarius, De ecclesiasticis officiis (PL 105, 996).

56 Cf. Rupertus, Liber de divinis officiis (PL 170, 97).

57 Cf. Rabanus Maurus, De clericorum Institutione (PL 107, 346-347).

58 Cf. Beda Venerabilis, De Officiis libellus (PL 94, 533); Alcuinus, De divinis officiis (PL 101, 1182-1183); Joannes Belethus, Rationale divinorum officiorum (PL 202, 84); Ożóg - Pietras, Księga Pontyfików 1-96, IX, 58*; Davril - Thibodeau, Gvillelmi Dvranti Rationale, 226.
} 
the associated custom of sprinkling ashes on the heads of penitents. In fact it is only from the tenth century that ashes have been sprinkled on the heads of all the faithful, as a sign of beginning a period of penance, but theologians were already referring to this gesture in the early allegorical interpretation of the liturgy ${ }^{59}$ Through the sprinkling of ashes on the head, man is to be made aware of the transience of his life, and at the same time it encourages him to do penance in hairshirt and ashes. ${ }^{60}$ Rupert of Deutz also recommended the sprinkling, in a spiritual manner, of ashes onto the heart since, he explained, man has a heart of stone while still on this earth (cf. Ezra 11:19). For ashes are a sign that people are not gods from heaven, but mortals made from the dust of the earth. ${ }^{61}$

When explaining the meaning of forty days of penance, medieval theologians often appealed to biblical texts. Amalarius of Metz explained that the time of Lent is a special symbol of a spiritual battle having commenced. First of all, he applied this time to the forty generations in the genealogy of Christ (cf. Matt 1:1-17). Citing St. Augustine, Amalarius of Metz called attention to the fact that the number forty is an image of the temporal and difficult life on earth. Secondly, the author recalls that this time period was sanctified by Moses and Elijah, and, notably, by Christ. ${ }^{62}$ The Venerable Bede also refers to these images. At the same time, he shows the ongoing relationship between the Quadragesima and the forty days after the resurrection: in this life there is a time of sadness, and in the future, joy. ${ }^{63}$ Besides Moses and Elijah, Honorius of Autun also gave the example of Daniel, who fasted for three weeks, accepting no food from the royal table (cf. Dan 10:2-3). Another image is the exodus of the Israelites from Egypt. He taught that at this time the Israelites had food from heaven and drink from the earth, until they came to the land flowing with milk and honey (cf. Exod 3:8). Similarly the faithful, nourished by the Body and Blood of Christ, and keeping the Decalogue and the precepts of the four Gospels (to multiply these numbers: ten times four equals forty), come to the true land flowing with milk and honey-to the land of the living. In connection with this thought, he also preached that there are three reasons for fasting: to recall the suffering of Christ, to curb the passions to which nature is inclined, and to recall the entrance of the Israelites to the Promised Land and the return from the Babylonian captivity, which alludes to the resurrection of Christ and the entrance into the eternal kingdom. ${ }^{64}$ Hugo of St. Victor likewise discussed these questions. ${ }^{65}$

59 Cf. Martimort, Handbuch der Liturgiewissenschaft, 247.

60 Cf. Honorius Augustodunensis, Gemma animae (PL 172, 655).

61 Cf. Rupertus, Liber de divinis officiis (PL 170, 98).

62 Cf. Amalarius, De ecclesiasticis officiis (PL 105, 1001-1002).

63 "...ut ostenderet in praesenti vita tempus esse afflictionis, et in futuro gaudii" (Beda Venerabilis, De Officiis libellus [PL 94, 534-535]).

64 Cf. Honorius Augustodunensis, Gemma animae (PL 172, 655-656).

65 Cf. Hugo de S. Victore, De caeremoniis (PL 177, 445). 
For Rupert of Deutz the true image of the practice of penance was the fast of Christ in the desert. First the author explains his method of calculating the "Paschal Forty Days." In his writings he states that from the first Sunday of Lent to the Saturday preceding Easter Sunday there are in fact forty-two days, but because of Christian piety, only thirty-six of these days carry the obligation of abstinence and penance. This is because the Sundays of Lent are not to be counted as fast days. Considering, though, that the entire year numbers three hundred and sixty days, thirty-six days constitute one-tenth of that time; and after adding four days from Ash Wednesday, there are exactly forty days of fast. ${ }^{66}$

For Amalarius of Metz the foundation of the topic of the length of the "Paschal Forty Days" was the number forty-six. This is the number of days separating Ash Wednesday from Holy Saturday. According to him the number refers to the years when the Temple of Jerusalem was built, and this was an image of the temple of the Body of the Lord (cf. John 2:20-22). Amalarius of Metz calls upon the interpretation of St. Augustine, who, writing the Greek words for the four directions of

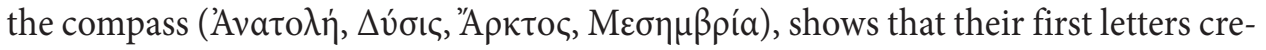
ate the name Adam. Bearing in mind Greek numbers, the author underscores that in the word ADAM the letter $\alpha^{\prime}$ appears twice, so, two; the letter $\delta^{\prime}$, four, so, together, six; and the letter $\mu^{\prime}$, that is to say forty, which gives a sum of forty-six. ${ }^{67}$ Hugo of St. Victor also alluded to the construction of the Temple of Jerusalem in forty years. ${ }^{68}$

Medieval theologians laid stress on the spiritual significance of the forty-day time period of penance. One example is Amalarius of Metz, who compared the time of Lent to a battle in a war campaign. This struggle was to take place through fasting, tears, and lamentation (cf. Joel 2:12), and remaining steadfast in truth..$^{69}$ Honorius of Autun proclaimed that the six weeks of Lent are an image of the six evangelical works by which it is possible to atone for sin. These are: to satisfy the hungry with the bread of life; to give drink to those thirsting for justice; to attire those yearning for holiness; to welcome wanderers seeking conversion; to visit the sick; and to free prisoners from evil habits and tendencies. ${ }^{70}$

In addition to looking at the "Paschal Forty Days" as a whole, allegorical theologians described the significance of the six individual Sundays of Lent, whose theological content was structured by Pope Gregory the Great (590-604). ${ }^{71}$ Honorius of Autun related the Sundays of Lent to particular stages of the life of man in salvation history. The first was the period when man lived happily in paradise (cf. Gen 2:1-25);

66 Cf. Rupertus, Liber de divinis officiis (PL 170, 97); Davril - Thibodeau, Gvillelmi Dvranti Rationale, 248-250.

67 Cf. Amalarius, De ecclesiasticis officiis (PL 105, 1004).

68 Cf. Hugo de S. Victore, De caeremoniis, sacramentis (PL 177, 446).

69 Cf. Amalarius, De ecclesiasticis officiis (PL 105, 1002-1003).

70 Cf. Honorius Augustodunensis, Gemma animae (PL 172, 657).

71 Cf. Righetti, Lanno Liturgico, 160-161. 
the second, when he rejoiced after being saved from the flood (cf. Gen 8:14-22); the third, when Joseph rejoiced after his release (cf. Gen 41:1-57); fourth, when Solomon rejoiced in an era of peace (cf. $1 \mathrm{Kgs} 5: 1-8$ ); fifth, when the Israelites returned from the Babylonian captivity (cf. Ezra 3:1, 8; 31-33; Neh 2:10-11); the sixth reflects the time from the resurrection of the Lord until His ascension. These six stages, in his opinion, also signify the life of the individual person, from infancy to old age. ${ }^{72}$

Rupert of Deutz interpreted the individual Sundays in a different way. According to him, the first Sunday relates to the time up to the fourth epoch of the earth. During this time the world was created and the People of God entered into adulthood, when they were crowned with a kingly diadem and adorned with the wisdom of the prophets. ${ }^{73}$ The second Sunday is a symbol of the fifth epoch of the earth, from the destruction of the Temple and the Babylonian captivity. At that time the People of God had neither Temple nor altar, and they were forced to pray to false gods under the threat of punishment of being thrown into a fiery furnace. He also explains that there was no statio for this day, which is also confirmed by the notation vacat in the Gregorian Sacramentary. ${ }^{74}$ According to Rupert of Deutz, this also illustrates the gospel pericope of that day on the healing of the Canaanite woman's daughter, who was tormented by an evil spirit (Matt 15:21-28). This image gives hope that those in captivity will likewise be released. The third Sunday of Lent presents in a mystical way the sixth epoch of the earth. It recalls the Babylonian King Nebuchadnezzar, who symbolized the evil spirit; and also the fulfillment in Christ of the messianic promises which speak of healing the deaf and mute, and casting out of evil spirits (cf. Matt 11:2-6). At the same time, Rupert of Deutz refers to the vessels that were taken from the Temple of Jerusalem by Nebuchadnezzar, emphasizing that in the New Law these vessels, that is, people, cleansed in holy baptism from the former filth of sin, should not be stained again (cf. Eph 5:3). The fourth Sunday of Lent depicts the seventh epoch of the earth, that is, the sabbath rest. The image of this joy is expressed by innumerable crowds of the faithful, who after the resurrection receive two robes, namely of immortal glory of the soul and of the body. The liturgy for the station of the Basilica of the Holy Cross of Jerusalem fell on this day. This place was to intensify a longing for the heavenly Jerusalem among the faithful, presently pilgrims remaining far from the Lord (cf. 2 Cor 5:6) ${ }^{75}$ Alcuin had already drawn attention to the period of rest, but for him it was an image of the repose of all souls after death. ${ }^{76}$

\footnotetext{
Cf. Honorius Augustodunensis, Gemma animae (PL 172, 658).

Cf. Rupertus, Liber de divinis officiis (PL 170, 96).

Cf. Deshusses, Le Sacramentaire Grégorien, 141.

Cf. Rupertus, Liber de divinis officiis (PL 170, 98-103).

Cf. Alcuinus, De divinis officiis (PL 101, 1215).
} 


\section{Passiontide-the Preparation and Pffering of the Sacrifice}

Within the forty days of penance the time of the passion of the Lord is set apart, encompassing the final two weeks. This distinction came about probably at the turn of the $7^{\text {th }}$ and $8^{\text {th }}$ centuries, as the Old Gelasian Sacramentary has the name of the fifth Sunday of Lent written as Quinta Dominica quae pro scrutinio celebratur, while in the Gregorian Sacramentary the title Die Dominica de Passione ad sanctum Petrum ${ }^{77}$ is to be found. The First Sunday of the Passion began the observance of the passion of the Lord. Rupert of Deutz, seeking an answer as to why the passion of Jesus was contemplated so many days before his death, offers the words of the Gospel of the raising of Lazarus: "So the chief priests and the Pharisees convened the Sanhedrin and said, 'What are we going to do? This man is performing many signs. If we leave him alone, all will believe in him, and the Romans will come and take away both our land and our nation"' (John 11:47-48). He explains further why this pericope is assigned to this particular Sunday. It indicates that the beginning of the month, when the moon was new, fell on the sixth day of the week, that is, Friday. Christ was crucified on the sixth day of the week, which was also the fifteenth day of that month. The first day of that month fell on Friday of the fourth week of Lent. That is why the pericope of the raising of Lazarus was read that day as well. Rupert also concludes that Lazarus was resurrected on the day of the new moon. ${ }^{78}$

The statio for the First Sunday of the Passion was St. Peter's Basilica. ${ }^{79}$ Rupert of Deutz explained that since St. Peter is the first heir to the priesthood of Christ, and after Christ was the first high priest, who followed Christ to the end and was led where he did not want to go (cf. John 21:18), celebrating the statio of the church of St. Peter is most fitting for the mystery of that day. ${ }^{80}$

The culmination of the events of salvation takes place during Holy Week, which begins with the Second Sunday of the Passion, or Palm Sunday. In allegorical interpretation, Amalarius of Metz indicates the Saturday preceding this Sunday. He recalls a custom confirmed by one of the oldest liturgical sources, of the pope distributing alms to the poor on this day. This custom is attested to by a note in the Ordines Romani. ${ }^{81}$ Amalarius of Metz applies this custom to the gospel pericope of the anointing of Jesus' feet with costly oil (John 12:3), explaining that that which the woman did to Jesus, the Head, the same the pope does to the members of His Mystical Body. He calls this costly ointment "justice," quoting the commentary of St. Augustine. ${ }^{82}$

\footnotetext{
Cf. Mohlberg, Liber Sacramentorum, 39; Deshusses, Le Sacramentaire Grégorien, 160.

Cf. Rupertus, Liber de divinis officiis (PL 170, 119-121).

Cf. Deshusses, Le Sacramentaire Grégorien, 160.

Cf. Rupertus, Liber de divinis officiis (PL 170, 125).

"Domnus papa elemosinam dat"; Andrieu, Les Ordines Romani, 161.

Cf. Amalarius, De ecclesiasticis officiis (PL 105, 1007-1008).
} 
William Durand offers a similar interpretation..$^{83}$ According to Rupert of Deutz, in the early Middle Ages this was also a day with no statio in Rome; there was no proper text assigned to the Mass for this day, and for this reason it was marked vacat. ${ }^{84}$ A proper liturgical text does however appear in the Gregorian Sacramentary, and the statio is designated as: Ad sanctum Petrum quando helemosyna datur. ${ }^{85}$ Alcuin had referred to the custom of almsgiving on this day ${ }^{86}$, and Honorius of Autun explained that the pope should minister to the poor since, in accordance with the law of the gospel, this was his duty. ${ }^{87}$

Palm Sunday, which begins Holy Week, recalls the biblical events taking place before the passion and death of Jesus, such as the entry of Jesus into Jerusalem on a donkey, when he was welcomed by the crowds with palm branches in their hands (cf. Matt 21:1-9). Medieval theologians drew attention to the significance of the circumstances accompanying the entry into Jerusalem. Isidore of Seville says that the palm branch symbolizes the triumph over Satan by Christ on the cross, and the donkey upon which Jesus rode into Jerusalem, the simple hearts of the pagans. ${ }^{88}$ Rabanus Maurus ${ }^{89}$ also referred to this idea in his texts, as did Hugo of St. Victor. ${ }^{90}$ Also on this day, that is to say, the tenth day of the first month-as Amalarius of Metz, citing the Venerable Bede, notes-it was necessary to bring home the lamb which was to be sacrificed during the Pasch (cf. Exod 12:3). Jesus likewise came into Jerusalem on the tenth day, five days before the Pasch. ${ }^{91}$ Rupert of Deutz also referred to this motif and explained the significance of these events. He compares being called out from slavery under pharaoh to liberation from the power of the devil, which could not be done simply by ten plagues, nor even by keeping the Decalogue, but only by the death of Christ. This allowed him to show three relationships between the Old Testament and the event of the Redemption. These were: the slaying of a lamb by the Israelites and the death of Jesus as the Easter lamb; the killing of the firstborn in Egypt and the wiping away of original sin; and the crossing of the Red Sea, which became an image of baptism in the Blood of Christ. ${ }^{92}$ Honorius of Autun emphasized in his treatise that it was on this day that the Israelites crossed the Jordan dryshod and entered in full triumph into the Promised Land (cf. Josh 3:14-17) ${ }^{93}$ John Beleth referred to other events found at the basis of allegorical interpretation: first,

\footnotetext{
83 Cf. Davril - Thibodeau, Gvillelmi Dvranti Rationale, 320.

84 Cf. Rupertus, Liber de divinis officiis (PL 170, 128-129).

85 Cf. Deshusses, Le Sacramentaire Grégorien, 166.

86 Cf. Alcuinus, De divinis officiis (PL 101, 1199-1200).

87 Cf. Honorius Augustodunensis, Gemma animae (PL 172, 662).

88 Cf. Isidorus Hispalensis, De ecclesiasticis officiis (PL 83, 763).

89 Cf. Rabanus Maurus, De clericorum Institutione (PL 107, 347).

90 Cf. Hugo de S. Victore, De caeremoniis, sacramentis (PL 177, 447-448).

91 Cf. Amalarius, De ecclesiasticis officiis (PL 105, 1008).

92 Cf. Rupertus, Liber de divinis officiis (PL 170, 129-130).

93 Cf. Honorius Augustodunensis, Gemma animae (PL 172, 662).
} 
the entrance of the Israelites into the Promised Land; second, the arrival of Jesus in Jerusalem from Bethany; third, the expulsion of the moneychangers from the Temple in Jerusalem. ${ }^{94}$

Theologians presenting allegorical interpretation of the liturgy when discussion Holy Week drew attention to the relationship between the creation of the world and the Redemption. On Sunday, which is the first day of the week, God began the work of creation, and Christ, setting out on his pathway of suffering, began the work of Redemption, which ends on the seventh day with his being laid in the tomb. Rupert of Deutz stressed that as many days as God needed for the creation of the world, he devoted also to the salvation of man. This first day of salvation, then, is filled with euphoria, as when God created light (cf. Gen 1:3). ${ }^{95}$ In the same way, Rupert of Deutz sees in Monday of Holy Week the second day of creation, when God created the vault of the heavens and separated the waters (cf. Gen 1:6). He notes that this day is as it were of a lesser brightness, quoting the explanation of St. Jerome that the number two enjoys less dignity since it is divisible and does not create unity. The separation of the waters of the earth from the waters of the heavens illustrates the division between good and evil, and so he notes that it is fitting that the wording, that 'this was good,' is not added. This author passes over a creation interpretation of Tuesday but explains the significance of Wednesday of Holy Week, the fourth day, when God created the heavenly bodies, that they might govern the day and the night (cf. Gen 1:14-19). On this day Christ as the Sun of Justice (cf. Mal 3:20) was sold by Judas (cf. Luke 22:3-6), that man might be saved. Developing this thought, he emphasized that in accordance with the idea of the prophet Isaiah, man had been sold for nothing and will be redeemed without money (cf. Isa 52:3). For without prior merit, but only because of grace, Christ who was betrayed bought back humanity, who had been sold. Amalarius of Metz interprets this day slightly differently. He said that on this day we recall Christ as the second Adam, who dies for the first Adam. ${ }^{96}$

The medieval theologians dedicated the most attention in their liturgical treatises to the Paschal Triduum. It is necessary however to emphasize that they did not differentiate these days but treated them as integral within the whole of Holy Week. Honorius recalls the four events which form the Holy Thursday liturgy: the reconciliation of sinners, the blessing of the oils, the commandment of love, and Jesus' giving the apostles his Body as food. ${ }^{97}$ John Beleth treats these issues somewhat differently. $\mathrm{He}$ also mentions four events, but according to him the are: first, reconciliation of sinners; second, the fact that on this day the New Testament begins and the Old ends; third, the consecration of oil; and fourth, the commandment of love. ${ }^{98}$ Rupert

\footnotetext{
94 Cf. Joannes Belethus, Rationale divinorum officiorum (PL 202, 95).

95 Cf. Rupertus, Liber de divinis officiis (PL 170, 131-138).

96 Cf. Amalarius, De ecclesiasticis officiis (PL 105, 1009).

97 Cf. Honorius Augustodunensis, Gemma animae (PL 172, 662).

98 Cf. Joannes Belethus, Rationale divinorum officiorum (PL 202, 96).
} 
of Deutz relates Holy Thursday to the fifth day of creation, when living beings were called forth, to live in the air, the earth, and the water (cf. Gen 1:20-22). ${ }^{99}$

First of all, theologians of the allegorical interpretation of the liturgy explain the ritual of the blessing of the oils during the Chrism Mass. They connected this to the custom of carrying covered vessels of oil. Amalarius of Metz interpreted the blessing of the oils in a Christocentric way, emphasizing that a vessel with the cross symbolizes, in a way, the Body of Christ. It, likewise, was for some time "hidden" and unknown to others, and for a certain time it was uncovered. He showed this tension based on events of the bible: when he escaped from the king into the desert, but is King of kings and Lord of lords; when he was taken to the Temple, but he is the Almighty; when his parents searched for him among their relatives and friends, and he is the omnipresent One; when he taught in the temple, and he is the source of wisdom; and when he was obedient to his parents, but he is their Creator. ${ }^{100}$ Rupert of Deutz pointed out in turn that the chrism is a sign of the Holy Spirit and carries His power. The cross is at the same time the fruit of the olive tree, which is "the tree of peace," and servant of the light, and mixed with balsam, has an exceptional fragrance. Moreover, the scent of balsam is an image of the sweetness of the Holy Spirit and the gift of grace, and man becomes pleasing to God in the fragrance of Christ, spreading to every place the aroma of the knowledge of him (cf. 2 Cor 2:14-15). Rupert of Deutz also links in a vivid way the significance of the chrism to the Mass of the Lord's Supper. During this month, the fourteenth day recalls the event of the exodus of the Israelites from the slavery of Egypt, when it was necessary to slaughter a lamb and sprinkle the doorposts and threshold of the house with its blood (cf. Exod 12:6-7). In the same way, anointing the forehead with chrism is meant to protect a person's soul and body from the angel of deathSatan. ${ }^{101}$ According to Isidore of Seville the preparation of the chrism points to the anointing of Jesus in Bethany before his passion (cf. Matt 26:6-12); ${ }^{102}$ Rabanus Maurus wrote about this later, as well. ${ }^{103}$

In accordance with ancient Church tradition, it was necessary to wash and clean the altar, the church floor, and the altar vessels on Holy Thursday. These activities were also interpreted in an allegorical manner. Amalarius of Metz emphasized that the floor of the church symbolized students taking in the instruction of a teacher, and that the washing was a symbol of the washing of the feet of the brethren and signified the forgiveness of sins. ${ }^{104}$ This washing, then, related to the practice of the rec-

\footnotetext{
99 Cf. Rupertus, Liber de divinis officiis (PL 170, 138).

100 Cf. Amalarius, De ecclesiasticis officiis (PL 105, 1016-1017).

101 Cf. Rupertus, Liber de divinis officiis (PL 170, 140-141); Davril - Thibodeau, Gvillelmi Dvranti Rationale, 349-350.

102 Cf. Isidorus Hispalensis, De ecclesiasticis officiis (PL 83, 764).

103 Cf. Rabanus Maurus, De clericorum Institutione (PL 107, 347).

104 Cf. Amalarius, De ecclesiasticis officiis (PL 105, 1019-1020).
} 
onciliation of sinners, since on this day Christ the High Priest in the fulness of his mercy intercedes before God, because he himself as Priest became also the Victim (cf. John 18:12). ${ }^{105}$ For John Beleth this cleansing does not mean simply maintaining external purity, but was a sign of the poor in spirit, whom it is necessary to help. ${ }^{106}$ Addressing this question more broadly, William Durand gave three reasons for Jesus' washing the feet of his disciples. These were: a sign of love, a sign of humility, and a sign of the cleansing of the will in view of celebrating the holy mysteries. ${ }^{107}$ On this day also, the altar is stripped, which in accordance with allegorical interpretation was meant to symbolize the fleeing of the apostles, ${ }^{108}$ or the stripping of Christ. ${ }^{109}$ Meanwhile the cleansing of the altar with water and wine is linked in this interpretation to the outflowing of blood and water from the pierced side of Christ (cf. John 19:34), as noted by Hugo of St. Victor ${ }^{110}$ and Rupert of Deutz. ${ }^{11}$

Good Friday is the moment in which the Cross of Christ finds itself at the center of the liturgy. As Isidore of Seville noted, it is through the mystery of this sign that man is healed. This event relates to the tree of paradise and the sin of our first parents. ${ }^{112}$ Rabanus Maurus interprets this subject in the same way. ${ }^{113}$ Amalarius of Metz meanwhile emphasizes that since the guilt of Adam had spread out to the four corners of the world, in the same way the Body of Christ, spread out on the wood of the cross, has embraced the world anew with salvation. ${ }^{114}$ With regard to the creation of the world, Rupert of Deutz saw in Good Friday the sixth day of creation. For on the sixth day God created man, and on Good Friday, redeemed him in a manner even more wondrous. Christ crucified completed the mystery of the renewal of man when he said the words, "It is finished" (John 19:30), because it is on this day that he completed his work of restoring its original dignity to the world. Moreover, he pointed out that the Mass could not be celebrated on that day. The friends of the Lord cannot offer sacrifice on the day on which his enemies kill Christ, the true sacrifice (Non sacrificent amici, dum trucidant inimici). Rupert of Deutz interpreted the four dimensions of the cross itself on the spiritual level: its length, width, height, and depth. Four virtues are connected to these four dimensions: depth of faith, length of perseverance, height of hope, and breadth of charity. ${ }^{115}$

\footnotetext{
105 Cf. Rupertus, Liber de divinis officiis (PL 170, 142-143).

106 Cf. Joannes Belethus, Rationale divinorum officiorum (PL 202, 108).

107 Cf. Davril - Thibodeau, Gvillelmi Dvranti Rationale, 362.

108 Cf. Amalarius, De ecclesiasticis officiis (PL 105, 1023); Hugo de S. Victore, De caeremoniis (PL 177, 450).

109 Cf. Rupertus, Liber de divinis officiis (PL 170, 150-151); Davril - Thibodeau, Gvillelmi Dvranti Rationale, 367.

110 Cf. Hugo de S. Victore, De caeremoniis, sacramentis (PL 177, 451).

111 Cf. Rupertus, Liber de divinis officiis (PL 170, 151-152).

112 Cf. Isidorus Hispalensis, De ecclesiasticis officiis (PL 83, 764).

113 Cf. Rabanus Maurus, De clericorum Institutione (PL 107, 348).

114 Cf. Amalarius, De ecclesiasticis officiis (PL 105, 1031).

115 Cf. Rupertus, Liber de divinis officiis (PL 170, 153-159).
} 
Amid the celebrations of Good Friday medieval theologians gave an allegorical explanation of the rite of the transference of the Most Blessed Sacrament, and of Holy Communion. On this day, according to ancient Church tradition, no Mass is offered, and the liturgy is known as the Missa Praesanctificatorum. ${ }^{116}$ According to Rupert of Deutz, the two presbyters who were to transfer the Blessed Sacrament were an image of Joseph of Arimathea and Nicodemus, who with great respect laid the Body of Jesus in the grave. He compares Holy Communion to the manna which the Israelites received in the desert. Just as the sacrifice of Jesus was prepared in the Cenacle on the day before His death, so also has the sacrifice of Christ been prepared a day in advance-the fifth day-and brought to the sixth day, in accord with the command of the Lord, "I am going to rain down bread from heaven for you. Each day the people are to go out and gather their daily portion; thus will I test them, to see whether they follow my instructions or not. On the sixth day, however, when they prepare what they bring in, let it be twice as much as they gather on the other days" (Exod 16:4-5) ${ }^{117}$ In medieval times, to preserve on this day the savor of Holy Communion under both species, the Body of the Lord was immersed in unconsecrated wine. Alcuin mentions this custom. ${ }^{118}$ This corresponded to the teaching on the Eucharist of that time, familiar since the $9^{\text {th }}$ century. This "consecration" of wine is mentioned in liturgical resources into the $12^{\text {th }}$ and $13^{\text {th }}$ centuries. ${ }^{119}$

The final day commentated upon within the Paschal preparation time by the medieval allegorists was Holy Saturday. They assigned its allegorical significance to Old Testament events: since it was at midnight that the Angel of Death passed through Egypt to deal out death, so also at midnight would the Messiah come. ${ }^{120}$ Rupert of Deutz called this the most beautiful of all days, as there is no feast more beautiful than the triumph of Christ on that holy night when those born again through baptism in Christ are made new. Continuing this thought Rupert of Deutz teaches that just as the moon receives its brightness from the sun, so does the Church receive its light from the true sun, who is Christ. ${ }^{121}$ This day was seen as a day of rest after the labors of redemption, as was noted by Isidore of Seville, ${ }^{122}$ Rabanus Maurus, ${ }^{123}$ Honorius of Autun, ${ }^{124}$ and John Beleth. This last wrote that the following events resounded in those days: the sacrifice of Christ, the devastation of hell, the redemption

\footnotetext{
116 Cf. Righetti, Lanno Liturgico, 230-232.

117 Cf. Rupertus, Liber de divinis officiis (PL 170, 166-167).

118 Cf. Alcuinus, De divinis officiis (PL 101, 1211).

119 Cf. Righetti, Lanno Liturgico, 232.

120 Cf. Amalarius, De ecclesiasticis officiis (PL 105, 1033).

121 Cf. Rupertus, Liber de divinis officiis (PL 170, 168-170).

122 Cf. Isidorus Hispalensis, De ecclesiasticis officiis (PL 83, 766).

123 Cf. Rabanus Maurus, De clericorum Institutione (PL 107, 349-350).

124 Cf. Honorius Augustodunensis, Gemma animae (PL 172, 668).
} 
of the human race, the opening up of paradise, and the manifestation of the writings of the Old and New Testaments. ${ }^{125}$

The theologians of the middle ages, citing liturgical rites and biblical texts, introduced important content about the time of the passion, which formed the culminating moment of the paschal preparation period. The reference of the individual days of Holy Week to the days of creation is noteworthy, showing in this way the relationship between the Lord's work of Creation, and the Redemption of man.

\section{Conclusion}

Allegorical interpretation of the preparation time before the Pasch-from the viewpoint of the history of the liturgy-is an important element in understanding this liturgical period from the perspective of the entirety of theology of the liturgy, varied over the centuries. The authors in their writings present the most important topics concerning the paschal preparation period. First of all, their theological explanations touch on interpretations of the manner of calculating the seventy, sixty, fifty, and forty days of the fast. Here they draw attention to the significance of these numbers and their theological references. The majority of these authors quote texts of the Venerable Bede, according to whom the Septuagesima concluded on Saturday of the Octave of Easter; Sexagesima on Wednesday of the Octave of Easter; Quinquagesima on the Sunday of the Resurrection of the Lord; and Quadragesima on Holy Thursday. Although the texts offered for analysis are from authors from the $7^{\text {th }}$ through $13^{\text {th }}$ centuries, the viewpoints are often duplicated. Against the background of the great allegorists of the middle ages, Rupert of Deutz stands out for his originality of thought. One example of this is his interpretation of the paschal preparation period, the individual periods of which he applies to the seven epochs of the earth.

The interpretation of biblical texts deserves attention in allegorical explanation of the liturgy in reference to the paschal preparation. The Septuagesima period was first related to the seventy years of the Babylonian captivity. One exception was relating the Sexagesima to the dinars of a daily wage, which was characteristic of the thought of Amalarius of Metz. The forty days in their turn were related to the number of camps the Israelites made after their exodus from the land of Egypt, and also to the genealogy of Christ as well as to the time needed for building the Temple in Jerusalem. It is in fact only further on that interpretation of the paschal preparation time evokes the fast of Christ in the desert, to which Rupert of Deutz draws attention. In addition, he explains that the seventy years of Babylonian captivity, because of the grace of absolution from sin thanks to Christ, have been shortened to seventy 
days of fast. It is also necessary to take an eschatological view of the custom of refraining during this time from singing the Gloria or the Alleluia acclamation, as these are heavenly songs to be sung only after the rebirth in water and the Spirit. Honorius of Autun in turn emphasized that the six weeks of Lent are an image of the six evangelical works, by which it is possible to atone for sins through the six works of mercy of the Gospel.

While the time of preparation for the Pasch is perceived as a particular moment of struggle, it is however important to emphasize the depiction of the mutual relationship between the time of the creation of the world and the time of the redemption of man. This subject-matter points to the wealth there is in recognizing the time of preparing for the Pasch. The above research affirms that presenting historical heritage concerning the liturgy is not to simply show lifeless monuments of the past, but helps give a fuller understanding of the current celebration of the liturgy.

\section{Bibliography}

Alcuinus, De divinis officiis liber (PL 101, 1173-1286).

Alcuinus, Epistola LXXX. Ad Domnum Regem. De ratione Septuagesimae, Sexagesimae et Quinquagesimae (PL 100, 259-263).

Amalarius, De ecclesiasticis officiis (PL 105, 985-1242).

Andrieu, M., Les Ordines Romani du haut moyen Age (Louvain: Spicilegium Sacrum Lovaniense 1961) V.

Angenendt, A., "Religiosität und Theologie. Ein spannungsreiches Verhältnis im Mittelalter," Archiv für Liturgiewissenschaft 20/21 (1978/1979) 28-55.

Auf der Maur H., Feiern im Rhythmus der Zeit. I. Herrenfeste in Woche und Jahr. 5. Gottesdienst der Kirche. Handbuch der Liturgiewissenschaft (ed. H.B. Meyer) (Regensburg: Pustet 1983).

Baron, A. - Pietras, H. (eds.), Dokumenty soborów powszechnych (Źródła Myśli Teologicznej 24; Kraków: WAM 2001) I.

Baron, A. - Pietras, H. (eds.), Dokumenty synodów od 506 do 553 roku (Synody i Kolekcje Praw 8; Kraków: WAM 2014).

Beda Venerabilis, De Officiis libellus, ex quorumdam patrum dictis excerptus (PL 94, 531-540).

Bettenzoli, G., "Księga Ezdrasza i Księga Nehemiasza," Międzynarodowy komentarz do Pisma Świętego (ed. W.R. Farmer) (Warszawa: Verbinum 2001) 596-607.

Caesarius Arelatensis, Regula ad monachos (PL 67, 1097-1104).

Davril, A. - Thibodeau, T.M. (eds.) Gvillelmi Dvranti Rationale divinorvm officiorvm (Tvrnholti: Brepols 1998) V-VI.

Deshusses, J. (ed.), Le Sacramentaire Grégorien. Ses Principales Formes d'après les plus anciens Manuscrits (Fribourg: Éditions Universitaires Fribourg Suisse 1971) I.

Franz, A., Die Messe im Deutschen Mittelalter (Freiburg im Breisgau: Herder 1902).

Frontczak, B., "Alegoryczna interpretacja Liturgii Godzin w ujęciu Amalarego z Metzu," Seminare 28 (2010) 15-28. 
Gibson, M.D. (trans.), The Didascalia Apostolorum in English (London: Cambridge University Press 1903).

Häussling, A.A., "Allegorische Meßerklärung," Lexikon für Theologie und Kirche (ed. W. Kasper) (Freiburg - Basel - Wien: Herder 1993) I, 402-403.

Honorius Augustodunensis, Gemma animae sive De divinis officiis et antiquo ritu missarum, deque horis canonicis et totius annis solemnitatibus (PL 172, 541-737).

Hugo de S. Victore, De caeremoniis, sacramentis, officiis et observationibus ecclesiasticis (PL 177, 381-455).

Innocentius III, De sacro altaris mysterio. Libri sex (PL 217, 773-916).

Isidorus Hispalensis, De ecclesiasticis officiis (PL 83, 737-825).

Joannes Belethus, Rationale divinorum officiorum (PL 202, 9-166).

Kolping, A., "Amalar von Metz und Florus von Lyon," Zeitschrift für katholische Theologie 73 (1951) 424-464.

Martimort, A.G., Handbuch der Liturgiewissenschaft (Freiburg - Basel - Wien: Herder 1965) II.

Meßner, R., "Zur Hermeneutik allegorischer Liturgieerklärung in Ost und West," Zeitschrift für katholische Theologie 115 (1993) 284-319; 415-434.

Meyer, H.B. "Alkuin zwischen Antike und Mittelalter. Ein Kapitel frühmittelalterlicher Frömmigkeitsgeschichte," Zeitschrift für katholische Theologie 81 (1959) 306-350; 405-454.

Meyer, H.B., "Meßerklärung heute," Zeitschrift für katholische Theologie 98 (1976) 422-439.

Mohlberg, L.C. (ed.), Liber Sacramentorum Romanae Aeclesiae ordinis anni circuli (Roma: Herder 1960).

Monumenta vetera ad Arianorum historiam pertinentia. Sermones Dominicales IV (PL 13, 641-652).

Nadolski, B. (ed.), Leksykon liturgii (Poznań: Pallottinum 2006).

Ożóg, M. - Pietras, H. (eds.), Księga Pontyfików 1-96 (Synody i Kolekcje Praw 9; Kraków: WAM 2014).

Rabanus Maurus, De clericorum Institutione ad Heistulphum Archiepiscopum libri tres (PL 107, 293-419).

Righetti, M., Lanno Liturgico. II. Manuale di storia liturgica (Milano: Àncora 1969).

Rupertus, Liber de divinis officiis (PL 170, 9-332).

Walafridus Strabus, De ecclesiasticarum rerum exordiis et incrementis (PL 114, 919-966).

Zahajkiewicz, M., "Expositio missae," Encyklopedia katolicka (eds. E. Gigilewicz et al.) (Lublin: Towarzystwo Naukowe KUL 1989) IV, 1467-1468. 
